\title{
Effects of multicomponent brine on functional and technological properties of camel meat raw materials and finished products
}

\author{
Shynar I. KENENBAY ${ }^{1}$, Aigul M. TAYEVA ${ }^{1}$, Zhibek K. USSEMBAEVA ${ }^{1}$, Laila S. SYZDYKOVA ${ }^{1}$, \\ Leila A. KAIMBAYEVA ${ }^{2 *}$ (D), Madina O. KOZHAKHIYEVA ${ }^{1}$
}

\begin{abstract}
The purpose of this study is a theoretical rationale and practical implementation of the technology of the production of national meat products with increased food and biological value based on a differentiated use of camel meat cuts. To achieve this aim the following tasks were specified: to investigate the effects of herbal additives to the brine and vegetable-protein compositions on the structural, mechanical and consumer properties of camel meat and finished products, to investigate the effects of a multicomponent brine on the biochemical, diffusion and osmotic processes during camel meat salting; to justify an optimal composition of a multicomponent brine for camel meat salting and the amount of brine to be injected into the meat. During the study, scientific concepts, principles and integrated approaches to the development of food products with specified properties were used based on standard and special methods for data collection and analysis, as well as systematization of the results. To carry out a comprehensive assessment of the quality of raw materials and finished products, conventional, standard and special methods for organoleptic and physicochemical parameters, nutritional value and safety, were used. The results of the study showed that the use of herbal additives to the composition of the injected brine was aimed at an increase of the cohesion-adhesion processes in the meat system.
\end{abstract}

Keywords: protein systems; toxic elements; herbal raw material; superoxide dismutase.

Practical Application: Improvement the functional and technological characteristics during production of camel meat products.

\section{Introduction}

The use of brines with herbal additives to be injected is a promising direction in the production of whole muscle meat products. Brine injection directly into raw meat greatly accelerates the salting time. After the forced injection into the raw meat, the brine components are more evenly distributed in the product. Thereby conditions for the use of components (polysaccharides, protein products, large spice particles, etc.), which could hardly penetrate when distributed over the raw meat surface, are provided. The injection through a hollow metal needle with holes introduced into the raw meat according to a certain scheme provides uniform brine distribution into the product. The salting mixture is introduced into the raw meat depth regardless of its morphological structure and muscle fibre orientation. Various devices could inject manually or automatically.

Since muscle tissue is dissected with needles during the brine injection process, the raw meat is additionally tenderized. This effect is taken into account by some manufacturers of multi-needle injectors using needles of various profiles and providing additional meat dissection.

The aim of numerous studies is to develop multicomponent protein systems used for meat salting. Protein systems includes: whole blood, serum and blood plasma, herbal extracts, edible fats, fatty acids, enzyme preparations, bacterial fermentation starters, milk proteins, etc. (Tayeva, 2016; Kaimbaeva \& Uzakov, 2015;
Uzakov \& Kaimbaeva, 2014; Tayeva \& Uzakov, 2016; Borisenko, 2008; Kryvonos et al., 2017; Talismanov et al., 2017; Silva et al., 2018). Multicomponent brines provide rational use of processed food products, increase the yield of the finished products and their nutritional and energy value, and physiological benefits with concomitant improvement of organoleptic parameters.

The brine of the specified concentration can be obtained by dilution of the concentrated brine with water or by mixing brines of different concentrations. If salt has high microbiological contamination, and for products with extended shelf life, the brine is either sterilized for 30 minutes at $120^{\circ} \mathrm{C}$, or boiled for 1.5 hours. Sodium nitrite, sugar is pre-dissolved in small amounts of brine or boiled water and added into the brine.

The choice and justification of the necessary and sufficient amount of formulation components in the brine for meat salting, which can have an intentional impact on changes in the functional and technological properties of camel meat during processing, were based on the comprehensive study of the functional and technological properties of the raw materials in determination of the optimal brine composition and stabilization of structural and mechanical, physicochemical and organoleptic characteristics of pilot samples of smoked-boiled camel meat product (Tayeva, 2016; Tayeva \& Uzakov, 2016; Kenenbay, 2016; Faye, 2013). 


\section{Materials and methods}

At the first stage of the work, we studied herbal raw materials (dry extract of Goji berries, oatmeal, oat grains) to obtain the appropriate composition of multicomponent brine for meat massaging. Herbal raw materials were tested for:

- toxic elements according to GOST 30178-96. The method is based on the product mineralization by dry or wet ashing while the element concentration in the mineralizing solution was determined by flame atomic absorption (Russian Standards and Technical Regulations, 1997);

- micro- and macroelements by atomic absorption according to GOST R 55484-2013 (Antipova et al., 2001);

- water-soluble vitamins, in $\mathrm{mg} / 100 \mathrm{~g}$, were determined using high performance liquid chromatography (HPLC) according to GOST R 55482-2013 (Antipova et al., 2001);

- antioxidant activity (AOA) by amperometric method, in $\mathrm{KI}^{\star} \mathrm{L} /\left(1000^{\star} \mathrm{mL}^{\star} \mathrm{min}\right)$, according to GOST R 54037-2010 using the antioxidant analyser Colour Yauza-01-AA (Russian Standards and Technical Regulations, 2011);

- catalase activity, $\mathrm{E}\left(\mathrm{molH}_{2} \mathrm{O}_{2}\right) / \mathrm{g}$. The method for determination of catalase activity is based on measuring amount of hydrogen peroxide degraded following an incubation of the enzyme sample;

- total SOD activity, U/mg, was determined by (Kumar \& Knowles, 1993) as modified (Sinkevich et al., 2011).

At the next stage of the study, the influence of a multicomponent brine on a camel meat, obtained from 3-year-old young animals, was studied. The young Bactrian camels were slaughtered at "DALA Company" slaughterhouse, Village of Zhosaly, Kyzylorda region, the Republic of Kazakhstan. The camel meat was injected with a multicomponent brine and the physicochemical, functional and technological, and structural and mechanical parameters were determined as follows:

- water-holding capacity (WHC), in\%, by the method of sequential determination of the basic functional properties of minced meat from one sample, developed by scientists of All-Russian Meat Research Institute R.M. Salavatulina, V.I. Lyubchenko (Antipova et al., 2001);

- water-binding capacity (WBC), in\%, by Grau-Hamm pressure method (Antipova et al., 2001);

- shear force, $\mathrm{kg} / \mathrm{cm}^{2}$. From samples of meat after weight loss determination during thermal processing with probe No. 5 (diameter $10 \mathrm{~mm}$ ), samples were cut along the fibres to determine the cutting force on a Warner-Bratzler shear machine;

- $\mathrm{pH}$ of meat and meat products, in units, by the concentration of hydrogen ions using the potentiometric method at a hydromodule of 1:10 according to GOST R 51478-99 (Russian Standards and Technical Regulations, 2010).
- losses after thermal processing by the difference in the sample weight before and after boiling, in \%.

Amounts of ingredients in the brine were calculated taking into account the established standards of their use and their limits in the finished product and the ratio of brine amount to injected raw meat weight after injections according to the Formula 1 (Efremova \& Zabashta, 2009):

$\mathrm{X}=\mathrm{C}_{\mathrm{k}} \times \mathrm{C}_{\mathrm{n}} / \mathrm{K}_{\mathrm{p}}$

where: $X=$ concentration of the ingredient required in the brine to be injected, $\% ; C_{k}=$ content of the ingredient required in raw product after brine injection, $\% ; C_{n}=$ weight of the product after injection, \% to the raw product; $K_{p}=$ amount of brine to be injected into the product, $\%$ to the raw meat weight.

\section{Results and discussion}

The purpose was to prepare a multicomponent brine for massaging meat and to investigate its effect on the functional and technological properties of raw camel meat and finished products. To justify the choice of herbal raw materials, the characteristics of herbal raw materials have been studied (Table 1).

The results of the study of herbal raw materials showed the usefulness of herbal additives in the formulation of brines for camel meat salting.

The antioxidant activity of herbal components is of interest. Superoxide dismutase is an antioxidant protective enzyme that catalyses dismutation of singlet oxygen produced when electrons pass through the respiratory chain. SOD protects cells from free radicals and thereby from radical damage. In normal metabolism, superoxide dismutases maintain constant concentrations of superoxide radicals at the desired level protecting cells from the negative influence of the oxygen radicals (Carlos et al., 2016). Based on the successful SOD treatment of inflammatory processes, this enzyme can be considered as an alternative to corticosteroids. Goji berries can increase SOD levels and contain high levels of vitamins, which may indicate the high healing potential of Goji berries (Huang et al., 2003; Zhao et al., 2005; Li et al., 2007; Amagase et al., 2009).

Dry extract of Goji berries contains polysaccharides, 19 amino acids (8 of them are essential amino acids), minerals (potassium, sodium, calcium, magnesium, iron, copper, manganese, zinc and others). Goji berries contain considerable amount of vitamins $\mathrm{B}$, vitamins $\mathrm{A}, \mathrm{C}$ and $\mathrm{E}$, carotenoids: beta-carotene, lutein, lycopene, xanthophyll, essential fatty acids, such as linoleic acid. Polysaccharides are the most important functional components in Goji berries.

Pumpkin powder contains a large amount of carotene and vitamins $\mathrm{A}, \mathrm{K}, \mathrm{B}$ and $\mathrm{E}$, ascorbic acid, zinc salts, mineral salts, proteins and fats. The most unique component of the pumpkin powder is vitamin $\mathrm{K}$, which is not found in any other vegetables. However, the most valuable component in a pumpkin powder is pectin. Based on analysis of literature data and experimental studies, pumpkin and Goji berry dry powders can be used in the production of camel meat products. 
Experimental studies of the optimal formulation of a multicomponent brine were conducted. The control and experimental samples of smoked and boiled meat products were developed to determine the optimal brine formulation. The amount of brine injected into the control and test samples of whole muscle cuts is $10 \%$ of the initial raw meat weight. For the purpose of substantiating the choice of herbal ingredients and their amount in a multicomponent brine, samples with 12 brine variants were developed. In the experimental brine samples, the dose of sodium nitrite to be injected was reduced by $50 \%$, and the pumpkin powder and Goji berries extract were included in formulations at various ratios (Table 2). Table 3 shows the results of studies to determine the optimal formulation of multicomponent brine.

The injection of brine at a different ratio of pumpkin powder and dry extract of Goji berries into camel meat showed the highest increase in water-binding and water-holding capacities in test No. 6. An important qualitative parameter of meat products is their consistency investigated using the shear stress index. The obtained data showed that the introduction of multicomponent brine affects the consistency of the finished camel meat product, while the shear force varies depending on the ratio of the pumpkin and Goji berry powders. The optimal parameter is the shear force index in test No. 6, which also correlates with the organoleptic properties of this sample.

The results showed that the offered brines have an impact on the quality of the finished camel meat products which get stable colour and gentle consistency due to the high water-holding capacity of the meat system. In further tests, brine was used in the test samples according to the formulation given in Figure 1.

In accordance with the classical technology, salting provide the following steps: brine injection, massaging, curing. Penetration of multicomponent brine ingredients into muscle tissue is characterized by complex diffusion processes with some amount of water, proteins, and extractives passing into the brine. When exposed to the brine, muscle tissue increases in volume, and $\mathrm{pH}$ level changes (to acidic). Raw meat injections increase muscle fibre absorption of the brine components, while the production cycle shortens and the yield of finished products increases. Intensive salting treatment (massaging) of raw meat

Table 1. Characteristics of herbal raw materials.

\begin{tabular}{|c|c|c|c|}
\hline \multirow{2}{*}{ Test } & \multicolumn{3}{|c|}{ Herbal raw material } \\
\hline & Goji berry extract dry & Oatmeal & Oat grains \\
\hline \multicolumn{4}{|l|}{ Toxic elements, mg/kg, incl. } \\
\hline Lead & $0.2 \pm 0.07$ & $0.23 \pm 0.08$ & $0.21 \pm 0.07$ \\
\hline Arsenic & $0.017 \pm 0.005$ & $0.016 \pm 0.006$ & less than 0.008 \\
\hline Cadmium & less than 0.01 & less than 0.01 & less than 0.01 \\
\hline Mercury & less than 0.002 & less than 0.002 & less than 0.002 \\
\hline \multicolumn{4}{|l|}{ Micro- and macroelements } \\
\hline Magnesium, mg/100 g & $55.09 \pm 11.08$ & $31.49 \pm 6.3$ & $6.47 \pm 1.29$ \\
\hline Calcium, mg/100g & $4.24 \pm 0.42$ & $2.48 \pm 0.25$ & not determined \\
\hline Selenium, mg/kg & not detected & not detected & not detected \\
\hline \multicolumn{4}{|l|}{ Vitamins, $\mathrm{mg} / 100 \mathrm{~g}$} \\
\hline Vitamin E & 7.2 & 1.4 & 0.6 \\
\hline Vitamin A & 1.4 & 0.05 & 0.02 \\
\hline Vitamin D & 0.9 & 0.1 & 0 \\
\hline \multicolumn{4}{|l|}{ Antioxidant activity } \\
\hline Antioxidant activity, $\mathrm{KI}^{*} \mathrm{~L} /\left(1000^{*} \mathrm{~mL}^{*} \min \right)$ & $1.14 \pm 0.03$ & not found & $1.77 \pm 0.11$ \\
\hline Catalase activity, $\mathrm{E}\left(\mathrm{molH}_{2} \mathrm{O}_{2}\right) / \mathrm{g}$ & $0.039 \pm 0.011$ & $0.216 \pm 0.048$ & $0.009 \pm 0.001$ \\
\hline SOD activity, E/mg of the sample & $95.82 \pm 0.82$ & $1.44 \pm 0.41$ & not found \\
\hline
\end{tabular}

SOD activity = superoxide dismutase activity. Superoxide dismutase (SOD) belongs to the group of antioxidant enzymes.

Table 2. Formulation of brines to be injected.

\begin{tabular}{|c|c|c|c|c|c|c|c|c|c|c|c|c|c|}
\hline \multirow{3}{*}{ Name of ingredients } & \multicolumn{13}{|c|}{ Content of salting ingredients, kg per $100 \mathrm{~kg}$} \\
\hline & \multirow{2}{*}{$\begin{array}{c}\text { In } \\
\text { control } \\
\text { brine }\end{array}$} & \multicolumn{12}{|c|}{ In test brine } \\
\hline & & 1 & 2 & 3 & 4 & 5 & 6 & 7 & 8 & 9 & 10 & 11 & 12 \\
\hline Salt (sodium chloride) & 13.500 & 13.500 & 13.500 & 13.500 & 13.500 & 13.500 & 13.500 & 13.500 & 13.500 & 13.500 & 13.500 & 13.500 & 13.500 \\
\hline Sugar & 0.500 & 0.500 & 0.500 & 0.500 & 0.500 & 0.500 & 0.500 & 0.500 & 0.500 & 0.500 & 0.500 & 0.500 & 0.500 \\
\hline Sodium nitrite & 0.075 & 0.038 & 0.038 & 0.038 & 0.038 & 0.038 & 0.038 & 0.038 & 0.038 & 0.038 & 0.038 & 0.038 & 0.038 \\
\hline Water & 85.925 & 85.000 & 85.000 & 84.000 & 84.500 & 84.500 & 83.000 & 84.000 & 84.000 & 82.000 & 83.500 & 83.500 & 81.000 \\
\hline Pumpkin juice dry powder & 0.000 & 1.000 & 0.000 & 1.000 & 1.500 & 0.000 & 1.500 & 2.000 & 0.000 & 2.000 & 2.500 & 0.000 & 2.500 \\
\hline Goji extract dry & 0.000 & 0.000 & 1.000 & 1.000 & 0.000 & 1.500 & 1.500 & 0.000 & 2.000 & 2.000 & 0.000 & 2.500 & 2.500 \\
\hline Total & 100.00 & 100.0 & 100.00 & 100.00 & 100.00 & 100.00 & 100.00 & 100.00 & 100.00 & 100.00 & 100.00 & 100.00 & 100.00 \\
\hline
\end{tabular}


provides faster and more uniform brine distribution, increases meat tenderness and water-binding capacity.

In this context, the influence of the mechanical method of raw meat processing (massaging) was simultaneously studied in the salting process, which increases the permeability of the sarcolemma and the membrane structures of muscle fibres for the components of salting mixtures, and activates muscle tissue enzymes.

In order to justify amount of multicomponent brine to be injected and massaging time, the influence of the brine dose injected and massaging time on lability of parameters (WBC, WHC, pH) were studied (Antipova et al., 2001; Russian Standards and Technical Regulations, 2010; Gombozhapova et al., 2017).

Changes in the hydrophilic capacity of camel meat were studied in the massaging process, and the results are presented in Figure 2 and Table 4.

The maximum increase in the water-binding capacity of the camel control sample up to $69.1 \%$ is achieved after 90 minutes of massaging when $20 \%$ of the brine is injected to the raw meat, and then reduced hydrophilic properties of meat due to physical destruction of muscle fibres are observed. The injection of brine containing dry powder of pumpkin and dry extract of Goji berries into the camel muscle tissue promotes the single matrix formation due to the interaction of polysaccharides with salt-soluble muscle proteins and cations, which increase the moisture-binding capacity of the sample. With further increase in the massaging time, the water-binding capacity of the camel meat is reduced. After massaging and salting, process parameters were determined in the salted camel meat (Table 4).

The experimental data analysis showed that the addition of additives to the multicomponent brine contributes to the process of water holding in the muscle tissue. Pumpkin powder and Goji berry extract have high swelling properties with increased WHC by $4.2,6.5$ and $7.5 \%$, which is explained by the presence of polysaccharides with high hydrophilic capabilities in the formulation. This is confirmed by the results of a weight loss study after thermal processing of salted camel meat (Table 5).

\section{Content of salting ingredients, kg per $100 \mathrm{~kg}$}

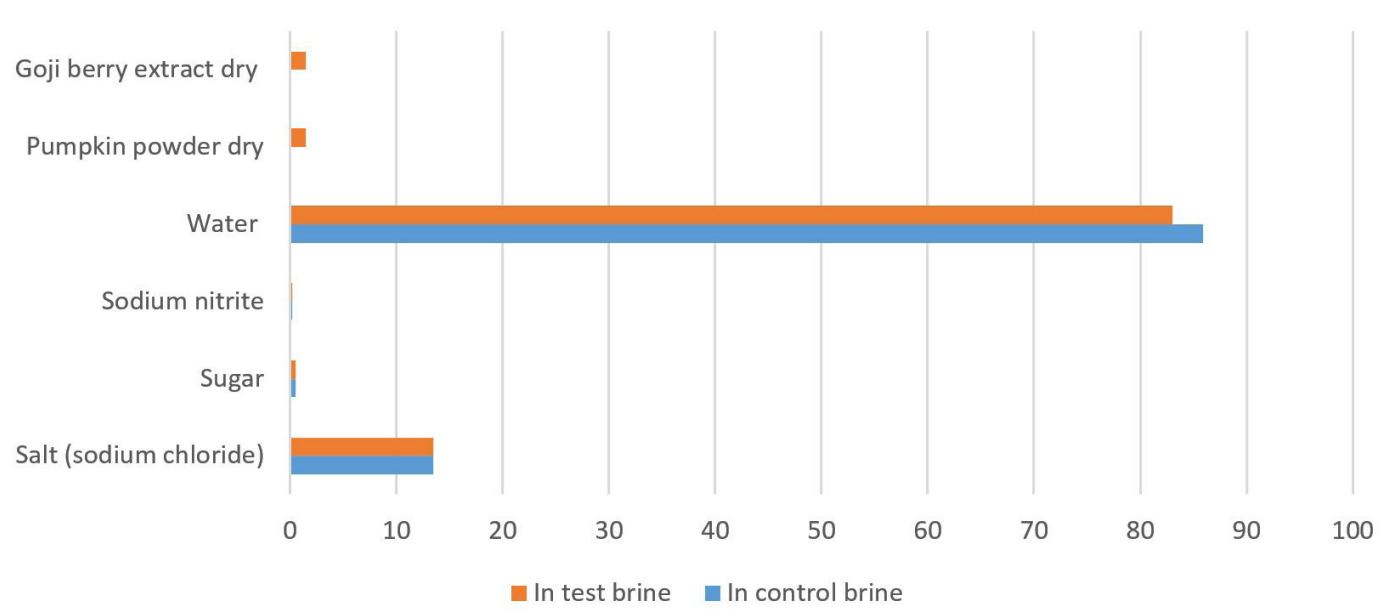

Figure 1. Formulation of an injected brine for camel meat salting.

Table 3. Determination of the optimal formulation of multicomponent brine.

\begin{tabular}{|c|c|c|c|c|c|c|}
\hline \multirow[t]{2}{*}{ Brine samples } & \multicolumn{2}{|c|}{$\begin{array}{l}\text { Content of components in kg per } 100 \mathrm{~L} \\
\text { of brine }\end{array}$} & \multirow[t]{2}{*}{ WHC, in \% } & \multirow[t]{2}{*}{ WBC, in \% } & \multirow[t]{2}{*}{ Shear force, $\mathrm{kg} / \mathrm{cm}^{2}$} & \multirow{2}{*}{$\begin{array}{l}\text { Organoleptic } \\
\text { parameters/mean }\end{array}$} \\
\hline & Pumpkin powder & Goji berry extract & & & & \\
\hline Test 1 & 1.0 & 0.0 & 63.15 & 67.92 & 17.2 & 3.20 \\
\hline Test 2 & 0.0 & 1.0 & 64.62 & 68.34 & 16.3 & 3.50 \\
\hline Test 3 & 1.0 & 1.0 & 66.9 & 70.20 & 15.4 & 3.70 \\
\hline Test 4 & 1.5 & 0.0 & 64.15 & 68.55 & 16.7 & 3.80 \\
\hline Test 5 & 0.0 & 1.5 & 65.8 & 68.9 & 16.3 & 4.00 \\
\hline Test 6 & 1.5 & 1.5 & 68.71 & 72.12 & 15.7 & 4.90 \\
\hline Test 7 & 2.0 & 0.0 & 68.35 & 70.75 & 14.8 & 3.60 \\
\hline Test 8 & 0.0 & 2.0 & 66.82 & 69.42 & 16.1 & 3.50 \\
\hline Test 9 & 2.0 & 2.0 & 68.22 & 71.45 & 14.5 & 3.50 \\
\hline Test 10 & 2.5 & 0.0 & 67.16 & 70.15 & 14.2 & 3.20 \\
\hline Test 11 & 0.0 & 2.5 & 67.8 & 71.1 & 16.4 & 3.20 \\
\hline Test 12 & 2.5 & 2.5 & 68.5 & 72.3 & 15.8 & 2.70 \\
\hline
\end{tabular}

$\mathrm{WHC}=$ water-holding capacity; $\mathrm{WBC}=$ water-binding capacity. 


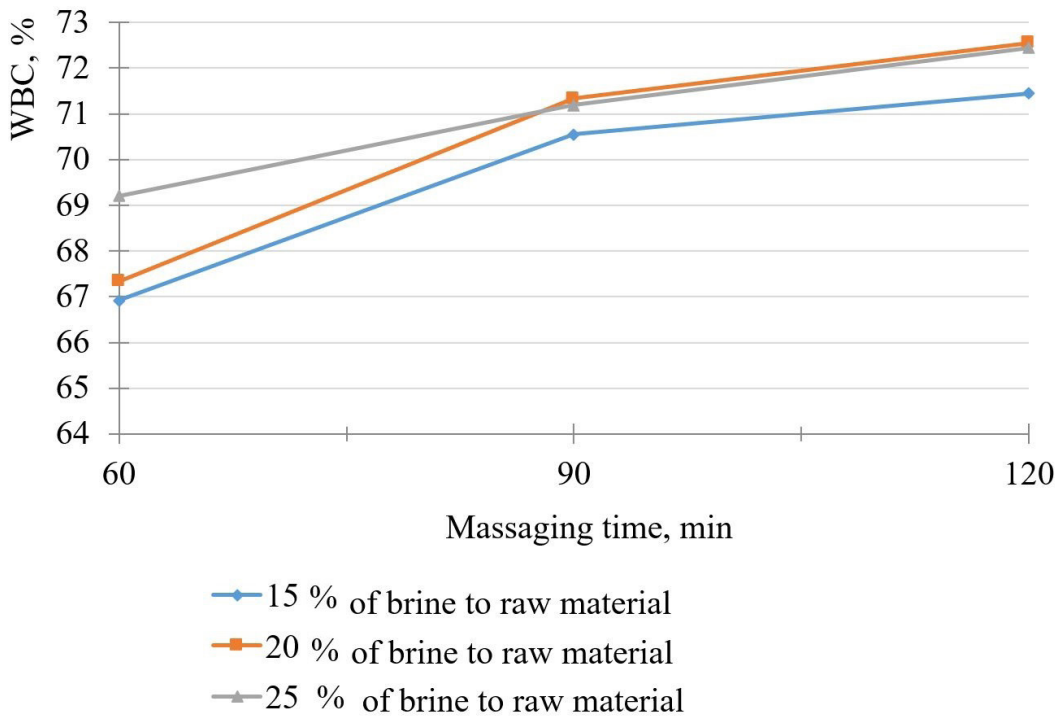

Figure 2. Changes in the water-binding capacity of camel meat, depending on amount of injected brine and massaging time.

Table 4. Technological parameters of salted camel meat.

\begin{tabular}{|c|c|c|c|c|}
\hline \multirow{3}{*}{ Tests } & \multicolumn{4}{|c|}{ Brine dose to be injected, in $\%$, to the raw meat weight } \\
\hline & \multirow{2}{*}{$\begin{array}{c}\text { Control } \\
10\end{array}$} & \multicolumn{3}{|c|}{ Model samples } \\
\hline & & 15 & 20 & 25 \\
\hline WHC, \% & $61.6 \pm 1.2$ & $65.8 \pm 1.6$ & $69.1 \pm 1.3$ & $69.5 \pm 1.1$ \\
\hline $\mathrm{pH}, \mathrm{U}$ & $5.80 \pm 0.1$ & $5.8 \pm 0.1$ & $6.0 \pm 0.1$ & $6.0 \pm 0.1$ \\
\hline Loss after thermal treatment, $\%$ & $28.2 \pm 0.4$ & $24.5 \pm 0.2$ & $21.9 \pm 0.5$ & $22.2 \pm 0.7$ \\
\hline
\end{tabular}

$\mathrm{U}=$ shear force, $\mathrm{kg} / \mathrm{cm}^{2}$; WHC $=$ water-holding capacity.

Table 5. Influence of brine amount and massaging time on the functional and technological parameters of camel meat products.

\begin{tabular}{ccccccc}
\hline No. & $\mathrm{x}_{1}$ & $\mathrm{x}_{2}$ & $\mathrm{y}_{1}$ & $\mathrm{y}_{2}$ & $\mathrm{y}_{3}$ & $\mathrm{y}_{4}$ \\
\hline Test 1 & 15 & 60 & 62.32 & 66.92 & 75.1 & 18.2 \\
Test 2 & 15 & 90 & 63.54 & 67.34 & 75.5 & 17.3 \\
Test 3 & 15 & 120 & 65.85 & 69.20 & 77.2 & 16.4 \\
Test 4 & 20 & 60 & 63.15 & 67.55 & 76.3 & 17.7 \\
Test 5 & 20 & 90 & 67.81 & 71.12 & 78.1 & 16.7 \\
Test 6 & 20 & 120 & 67.25 & 69.75 & 77.5 & 15.8 \\
Test 7 & 25 & 60 & 65.85 & 68.42 & 76.5 & 17.1 \\
Test 8 & 25 & 90 & 67.22 & 70.45 & 77.3 & 15.5 \\
Test 9 & 25 & 120 & 66.16 & 69.15 & 76.7 & 15.2 \\
\hline
\end{tabular}

$\mathrm{x}_{1}=$ the amount of injected brine to the mass of raw materials, \%; $\mathrm{x}_{2=}$ massaging time, min; $y_{1}=$ water-holding capacity; $y_{2}=$ water-binding capacity; $y_{3}$ yield, $\% ; y_{4}=$ shear force, $\mathrm{kg} / \mathrm{cm}^{2}$.

The use of herbal additives to the composition of the injected brine was aimed at an increase of the cohesion-adhesion processes in the meat system. The next stage of the work was experiments to determine the effect of the brine amount and the massaging time on the functional and technological parameters of finished camel meat products.

The massaging time varied from 60 to 120 minutes, as shown by the literature data analysis. The amount of multicomponent brine varied from $15 \%$ to $25 \%$, both for polysaccharide-containing brines (Ivanov et al., 2014; Font-i-Furnols et al., 2015; Devine \& Dikeman, 2014).
Table 5 shows that the brine amount and the massaging time have the impact on the functional and technological parameters of camel meat products. The best results are achieved in Test No. 5, where water-holding and water-binding capacities are higher than in the other variants. The shear force index correlates with WHC and WBC parameters, as further reduction of the shear force indicates that the product softens and gradually loses its ability to retain moisture, which have an impact on the organoleptic properties. These tables confirm the positive effect of multicomponent brine and mechanical treatment on the functional and technological characteristics of camel meat products.

\section{Conclusion}

The study of the characteristics of herbal materials supported the use of herbal additives in the composition of brines for camel meat salting. Analysis of the experimental data showed that these additives to the multicomponent brine contribute to the process of moisture retention in the muscle tissue. Pumpkin powder and Goji berry extract possess high swelling properties, therefore the WHC increases by $4.2,6.5$ and $7.5 \%$, which is explained by the presence in their composition of polysaccharides, which have a high hydrophilic capacity. This is confirmed by the results of the study of weight loss after thermal processing of salted camel meat.

The results of the study showed that the use of herbal additives to the composition of the injected brine was aimed at an increase of the cohesion-adhesion processes in the meat 
system. The amount of brine and duration of massaging affect the functional and technological characteristics of camel meat products. The best results were achieved in experiment No. 5, where the water-holding and water-binding capacity was higher than in other variants. The shearing force correlates with the parameters of the WHC and WBC, as further reduction of the shearing force indicates that the product softens and gradually loses its ability to retain moisture, which affects the organoleptic characteristics. Experimental data confirm positive effects of a multicomponent brine and mechanical treatment on the functional and technological characteristics of camel meat products.

\section{References}

Amagase, H., Sun, B., \& Nance, D. M. (2009). Immunomodulatory effects of astandardized Lycium barbarum fruit juice in Chinese older healthy human subjects. Journal of Medicinal Food, 12(5), 1159-1165. http://dx.doi.org/10.1089/jmf.2008.0300. PMid:19857084.

Antipova, L. V., Glotova, I. A., \& Rogov, I. A. (2001). Methods for researching meat and meat products. Moscow: Kolos.

Borisenko, L. A. (2008). Development of the technology for the production of sausages using activated liquid systems. Bulletin of Scientific Papers, 2(15), 100-102.

Carlos, T. D., Francisco, W., \& Guimarães, L. G. L. (2016). Evaluation of antioxidant activity of phenolic compounds present in Lippia sidoides cham leaves. Periódico Tchê Química, 13(25), 52-61.

Devine, C., \& Dikeman, M. (2014). Encyclopedia of meat sciences. Cambridge: Academic Press.

Efremova, A. S., \& Zabashta, A. G. (2009). Peculiarities of making and use of ground. Metals Technology, 10(82), 52-57.

Faye, B. (2013). Camel meat in the world. In I. Kadim, O. Maghoub, B. Faye \& M. Farouk (Eds.), Camel meat and meat products (pp. 7-16). Oxford: CAB International. http://dx.doi.org/10.1079/9781780641010.0007.

Font-i-Furnols, M., Čandek-Potokar, M., Maltin, C., \& Prevolnik Povše, M. (2015). A handbook of reference methods for meat quality assessment. Penicuik: SRUC Publisher.

Gombozhapova, N. I., Bazhenova, B. A., Leskova, S. Yu., Badmaeva, T. M., \& Danilov, A. M. (2017). Influence of the new multicomponent brine on the quality characteristics of the boiled horse meat product. Foods and Raw Materials, 5(1), 11-19. http://dx.doi.org/10.21179/23084057-2017-1-11-19.

Huang, X., Yang, M., Wu, X., \& Yan, J. (2003). Study on protective action of Lycium barbarum polysaccharides on DNA imparments of testicle cells in mice. Wei Sheng Yan Jiu, 32(6), 599-601. PMid:14963914.

Ivanov, S. V., Kishenko, I. I., \& Kryzhova, Yu. P. (2014). Substantiation of prescription components of multifunctional brine colloid systems of whole muscle products. Technology and Technology of Food Production, 32, 22-29.

Kaimbaeva, L. A., \& Uzakov, Y. M. (2015). The use of red deer meat and by-products in production of meat products. Meat Industry, 8(1), 40-43.
Kenenbay, Sh. I. (2016). Nutritional value of camel meat in the Republic of Kazakhstan. In C. Knowles (Ed.), The development of science in the 21st century: natural and technical sciences (Vol. 2, pp. 169-175). New York: Ron Bee \& Associates Company.

Kryvonos, Y. G., Romanov, V. O., Galelyuka, I. B., Wójcik, W., Zyska, T., \& Amirgaliyev, E. (2017). Independent devices and wireless sensor networks for agriculture and ecological monitoring. In W. Wójcik \& J. Sikora (Eds.), Recent advances in information technology (pp. 105-134). London: CRC Press.

Kumar, G. N., \& Knowles, N. R. (1993). Changes in lipid peroxidation and lipolytic and free-radical scavenging enzyme during aging and sprouting of potato (Solanum tuberosum L.) seed-tubers. Plant Physiology, 102(1), 115-124. http://dx.doi.org/10.1104/pp.102.1.115. PMid:12231802.

Li, X. M., Ma, Y. L., \& Liu, X. J. (2007). Effect of the Lycium barbarum polysaccharides onagerelated oxidative stress in aged mice. Journal of Ethnopharmacology, 111(3), 504-511. http://dx.doi.org/10.1016/j. jep.2006.12.024. PMid:17224253.

Russian Standards and Technical Regulations - RUNORM. (1997). GOST 30178-96: raw materials and food products. Atomic absorption method for the determination of toxic elements. Moscow: IPK Publishing House of Standards.

Russian Standards and Technical Regulations - RUNORM. (2010). GOST R 51478-99 (ISO 2917-74): meat and meat products. Control method for determining the concentration of hydrogen ions $(p H)$. Moscow: Standartinform.

Russian Standards and Technical Regulations - RUNORM. (2011). GOST R 54037-2010: food products: determination of the content of water-soluble antioxidants by amperometric method in vegetables, fruits, products of their processing, alcoholic and nonalcoholic beverages. Moscow: Standartinform.

Silva, E. V., Santos, A. A., Conceição, M. M., Carvalho, J. R. Fo., Paiva, Y. F., Silva, F. A., \& Oliveira, A. M. B. M. (2018). Evaluation of the functionality of extract of pout pepper as natural conservatives in the production of yogurt. Periódico Tchê Química, 15(29), 21-30.

Sinkevich, M. S., Naraykina, N. V., \& Trunova, T. I. (2011). Processes that prevent the increase of lipid peroxidation in cold-resistant plants under hypothermia. Plant Physiology, 58, 875-882.

Talismanov, V. S., Popkov, S. V., Karmanova, O. G., \& Zykova, S. S. (2017). Synthesis of 2-(4-aminophenyl)-4-triazolylmethyl1,3-dioxolanes: intermediates of biologically active compounds. Journal of Pharmaceutical Sciences and Research, 9(11), 1985-1988.

Tayeva, A. M. (2016). Creation of a brine composition for whole-muscle meat products. Scientific and Analytical Journal "Innovations and Investments", 6, 165-167.

Tayeva, A. M., \& Uzakov, Y. M. (2016). Innovative technologies of Kazakh national meat products. Almaty: Evero.

Uzakov, Ya. M., \& Kaimbaeva, L. A. (2014). The use of biochemical and physical effects in the salting of maral meat. Meat Industry, 2, 52-55.

Zhao, H., Alexeev, A., Chang, E., Greenburg, G., \& Bojanowski, K. (2005). Lycium barbarum glycoconjugates: effect on human skin and cultured dermal fibroblasts. Phytomedicine, 12(1-2), 131-137. http://dx.doi.org/10.1016/j.phymed.2003.08.002. PMid:15693720. 